\title{
Not only inner cell mass cell nuclei but also trophectoderm nuclei of mouse blastocysts have a developmental totipotency
}

\author{
Y. Tsunoda and Y. Kato \\ Laboratory of Animal Reproduction, College of Agriculture and Research Institute for Animal Developmental \\ Biotechnology, Kinki University, Nara 631-8505, Japan
}

\begin{abstract}
The nuclei of mouse trophectoderm cells were found to have developmental totipotency like inner cell mass cells after serial nuclear transfer. Single inner cell mass or trophectoderm cells from expanded blastocysts synchronized with the cell cycle by treatment with nocodazole and aphidicolin to the G1 stage were injected into the perivitelline space of enucleated metaphase II oocytes together with Sendai virus. All oocytes were given three electrical pulses to induce fusion and activation (first nuclear transfer). Aphidicolin was present in all media used until fusion. When reconstituted oocytes developed to the two-cell stage, the nuclei of the reconstituted eggs were fused with the enucleated blastomeres of fertilized two-cell embryos by inactivated Sendai virus (second nuclear transfer). The reconstituted embryos were cultured in vitro and transferred to recipients. After the second nuclear transfer, 23-64\% (for inner cell mass cells) and 32-62\% (for trophectoderm cells) developed to morula or blastocyst stage. Better development of second nuclear transfer embryos was observed when oocytes fused with trophectoderm nuclei did not extrude a polar body after the first nuclear transfer. After transfer of morulae and blastocysts to recipients, four males were obtained, two from inner cell mass and two from trophectoderm nuclei. These findings indicate that the nucleus of inner cell mass and trophectoderm cells of mouse blastocysts can be reprogrammed within the cytoplasm of unfertilized oocytes and then in fertilized embryos.
\end{abstract}

\section{Introduction}

The mammalian embryo first differentiates into two distinct cell lineages at the blastocyst stage (Handyside and Johnson, 1978; Hogan et al, 1994), one is the inner cell mass (ICM) which forms the embryo proper and the other is trophectoderm which contributes to formation of the placenta and fetal membranes. Nuclear transfer experiments in sheep (Smith and Wilmut, 1989) and cattle (Keefer et al., 1994; Collas and Barnes, 1994) suggest that the nuclei of some ICM cells have developmental totipotency. In contrast, studies on nuclear transfer into fertilized mouse zygotes with (Modlinski, 1981) or without (Illmensee and Hoppe, 1981) pronuclei and enucleated unfertilized rabbit oocytes (Collas and Robl, 1991) suggest that the developmental potential of trophectoderm nuclei is limited.

Nuclear transfer is a good technique with which to examine the potency of nuclei but it is necessary to consider the method used when ascribing totipotency. The developmental ability of nuclear transferred eggs is influenced by a combination of the cell cycle of the donor nucleus and the condition of the recipient cytoplasm (Campbell et al., 1996). For mice, two nuclear transfer systems have been reported. One is to fuse the nucleus at the GI stage to enucleated second metaphase (MII) oocytes (Cheong et al., 1993; Tsunoda and Kato, 1997) and the other is to fuse the nucleus at the G2 stage to enucleated

Revised manuscript received 28 January 1998. second anaphase oocytes (Kono et al,, 1992). Cheong et al. (1993) but not Tsunoda and Kato (1997) produced offspring by nuclear transfer of four- and eight-cell stage mouse embryos to enucleated oocytes. However, Tsunoda and Kato (1997) succeeded in obtaining offspring by a serial nuclear transfer of four-cell and compacted morula nuclei. In the first nuclear transfer, a nucleus at the G1 stage was fused with enucleated MII oocytes and reconstituted eggs were cultured to the two-cell stage. In the second nuclear transfer, both nuclei of reconstituted eggs were fused with enucleated blastomeres of fertilized two-cell embryos and reconstituted embryos were cultured to morulae and blastocysts before transfer to recipients.

The present study shows that, with serial nuclear transfer to enucleated oocytes and then to enucleated embryos, at least some nuclei from the trophectoderm as well as from the ICM cells of mouse blastocysts are able to support development to term.

\section{Materials and Methods}

\section{Isolation of ICM and trophectoderm cells}

Expanded blastocysts were recovered in medium M2 (Fulton and Whittingham, 1978) from non-albino $\mathrm{F}_{1}(\mathrm{C} 57 \mathrm{BL} \times \mathrm{CBA})$ females 4 days after mating with $F_{1}$ males. The zonae 
pellucidae were removed with $0.5 \% \quad(\mathrm{w} / \mathrm{v})$ pronase (Calbiochem-Biring Co., San Diego, CA) in M2. Zona-free blastocysts were cultured at $37^{\circ} \mathrm{C}$ in $5 \% \mathrm{CO}_{2}$ in air in medium M16 (Whittingham, 1971) supplemented with $3 \mu$ g nocodazole $\mathrm{ml}^{-1}$ (Aldrich Chemical Company, Milwaukee, WI) for $12 \mathrm{~h}$ to synchronize the cell cycle of nuclei to the $M$ phase (Kato and Tsunoda, 1995). For the preparation of ICM cells, they were then cultured in M16 supplemented with $3 \mu \mathrm{g}$ aphidicolin $\mathrm{ml}^{-1}$ (Sigma Chemical Co., St Louis, MO) for $\mathrm{th}$ to inhibit DNA synthesis (Kato and Tsunoda, 1995). The ICM was isolated by immunosurgery (Solter and Knowles, 1975). For the preparation of the trophectoderm, zona-free blastocysts were cultured for $1-3 \mathrm{~h}$ in the presence of aphidicolin to allow re-expansion of the blastocoel cavity. The mural trophectoderm was dissected carefully from the blastocysts microsurgically (Tsunoda et al., 1985). Single ICM or trophectoderm cells were obtained after treatment with PBS containing $0.01 \%(\mathrm{w} / \mathrm{v})$ trypsin and $0.02 \%(\mathrm{w} / \mathrm{v})$ EDTA or, in some cases, $200 \mathrm{iu}$ collagenase $\mathrm{ml}^{-1}$ (Sigma) and $10 \mu \mathrm{g}$ DNase $\mathrm{ml}^{-1}$ (Sigma). During the separation of ICM and trophectoderm cells, all media were supplemented with aphidicolin.

\section{Determination of DNA synthesis}

For examining the stage of the cell cycle of embryos synchronized with nocodazole and aphidicolin, an immunocytochemical system for monitoring cell proliferation using monoclonal anti-5-bromo-2'-deoxyuridine (BrdU) was used according to the manufacturer's protocol (cell proliferation kit, code RPW 20, Amersham, Bucks). Briefly, zona-free blastocysts were treated with nocodazole for $12 \mathrm{~h}$ and then cultured in M16 with or without aphidicolin in the presence of labelling reagent (BrdU) for $4 \mathrm{~h}$. The embryos were further treated with anti-BrdU, peroxidase anti-mouse $\operatorname{IgG}$ and then stained with anti-3,3'-diaminobenzidine tetrahydrochloride (DBA).

\section{Nuclear transfer}

Recipient oocytes were collected from $\mathrm{F}_{1}$ females $16-17 \mathrm{~h}$ after the injection of hCG, and chromosomes at MII were removed mechanically (Tsunoda and Kato, 1995). A single ICM or trophectoderm cell was injected into the perivitelline space of the enucleated oocyte with inactivated Sendai virus (HVJ; Tsunoda et al., 1986). The oocytes were transferred to Zimmerman's cell fusion medium in a chamber of two wire electrodes mounted I mm apart on a glass slide. All oocytes were given two DC pulses of $50 \mathrm{~V} \mathrm{~mm}^{-1}$ for $50 \mu$ s three times at $20 \mathrm{~min}$ intervals to induce fusion and activation. Aphidicolin was also added to all media used until fusion and oocytes were removed from medium containing aphidicolin after fusion. It took about $2 \mathrm{~h}$ from collection of oocytes to fusion and activation. The fused oocytes were cultured in M16. After $6 \mathrm{~h}$, they were examined for the formation of pronuclei and then those with pronuclei were cultured for a further $18-20 \mathrm{~h}$. The nuclei of the reconstituted eggs that developed to the twocell stage were fused with the enucleated blastomeres of an in vitro fertilized two-cell embryo by HVJ without electrical stimulation (Tsunoda and Shioda, 1988). Two-cell embryos in which the blastomeres were fused together were discarded.

\section{Embryo transfer}

The reconstituted embryos were cultured for 3 days in vitro and some embryos that had developed to the morula or blastocyst stage were transferred to the oviducts of day 1 pregnant albino CD-I strain females mated with the same strain males, which were subsequently allowed to go to term. Each female received one to three embryos.

\section{Results}

Incorporation of BrdU was observed in all of the five blastocysts treated with nocodazole and then cultured in M16 for $4 \mathrm{~h}$, and the proportion of positive nuclei was $26-44 \%$ in each blastocyst. However, incorporation was observed in only three of six blastocysts treated with nocodazole and then aphidicolin. Only $2-7 \%$ of nuclei were labelled in these embryos. Therefore, it was presumed that ICM and trophectoderm nuclei were at GI stage of the cell cycle when fused with the enucleated oocytes.

Two males were obtained from ICM nuclei and two from trophectoderm nuclei after transfer of 20 and 25 embryos developed from the serial nuclear transfer, respectively (Table 1). All males obtained were proven to be fertile after mating with two females. There was no difference between ICM and trophectoderm cells in the proportion of embryos that cleaved after the first nuclear transfer, or became morulae or blastocysts after the second transfer, or in the proportion of transferred embryos that developed to live young. Development of the embryos produced by the second nuclear transfer was much greater if donor cells fused to both blastomeres in the recipient embryo rather than to only one blastomere.

After the first nuclear transfer of trophectoderm cells, 101 of 219 oocytes formed one pronucleus. Only twenty seven $(27 \%)$ of the pronuclei had a polar body. Oocytes without $(63 / 74)$ or with $(19 / 27)$ a polar body developed to the two-cell stage. Twenty-five of 51 embryos and two of nine embryos from oocytes without or with a polar body, respectively, developed to morulae or blastocysts after the second nuclear transfer. However, after transfer to recipients, live young were obtained from reconstituted embryos by transfer of nuclei from two-cell embryos that developed from the oocytes that did not extrude a polar body.

Although polar body formation was not examined in all cases for the first nuclear transfer of ICM cells, none of the 49 oocytes examined had a polar body. After renuclear transfer, 36 embryos in which two nuclei fused to each blastomere and 13 embryos in which one nucleus fused to one blastomere were produced. Twenty-three of 36 and three of 13 embryos developed to morulae or blastocysts, two of 18 and none of three developed to live young, respectively.

\section{Discussion}

The results of the present study show that, with serial nuclear transfer to enucleated oocytes and then enucleated embryos, at 
Table 1. Developmental ability of nuclear transferred eggs receiving an inner cell mass (ICM) or trophectoderm (TE) cell from blastocysts

\begin{tabular}{|c|c|c|c|c|c|c|}
\hline \multirow[b]{2}{*}{ Donor } & \multicolumn{2}{|c|}{ First nuclear transfer } & \multicolumn{2}{|c|}{ Second nuclear transfer } & \multirow[b]{2}{*}{$\begin{array}{l}\text { Number of } \\
\text { recipients }\end{array}$} & \multirow{2}{*}{$\begin{array}{l}\text { Number of young } \\
\text { originated from } \\
\text { donor nucleus/ } \\
\text { transferred } \\
(\%)\end{array}$} \\
\hline & $\begin{array}{l}\text { Number of oocytes } \\
\text { with nucleus/ } \\
\text { used (\%) }\end{array}$ & $\begin{array}{l}\text { Number of oocytes } \\
\text { developed to } \\
\text { two-cell (\%) }\end{array}$ & Type* & $\begin{array}{c}\text { Number of eggs developed } \\
\text { to morulae or blastocysts/ } \\
\text { cultured (\%) }\end{array}$ & & \\
\hline \multirow[t]{2}{*}{ ICM } & $69 / 139(50)$ & $59(86)$ & Both & $23 / 36(64)$ & 13 & $2 / 18(11)$ \\
\hline & & & Half & $3 / 13$ & 1 & $0 / 2 \quad(0)$ \\
\hline \multirow[t]{2}{*}{$\mathrm{TE}$} & $101 / 219(46)$ & $82(81)$ & Both & $16 / 26(62)$ & 15 & $2 / 25$ \\
\hline & & & Half & $11 / 34$ & & \\
\hline
\end{tabular}

*Both, two karyoplasts from a two-cell egg after first nuclear transfer were fused with both blastomeres of enucleated two-cell embryos; half, a karyoplast was fused with a blastomere of enucleated two-cell embryos.

least some nuclei from mural trophectoderm as well as from ICM cells of mouse blastocysts are able to support development to term. Illmensee and Hoppe (1981) but not McGrath and Solter (1984) reported obtaining young after nuclear transfer of mouse ICM cells to enucleated zygotes. The developmental potency of trophectoderm nuclei of mouse blastocysts has been reported to be limited (Illmensee and Hoppe, 1981; Modlinski, 1981). The success of the present study may be due to the reprogramming of ICM and trophectoderm nuclei, not merely ICM nuclei, at GI occurs after fusion with enucleated oocytes and activation by electrical stimulation, as suggested by Campbell et al. (1996) for diploid nuclei from a cell line and by Cheong et al. (1993) for nuclei from two-eight-cell stage mouse embryos. Since our previous report (Tsunoda and Kato, 1997) showed that developmental ability was highest with the nucleus at the GI stage fused with cytoplasm at the $\mathrm{M}$ stage, in the present nuclear transfer, the donor nucleus at GI stage was fused with enucleated oocytes at the $\mathrm{M}$ stage. The stage of the cell cycle of the nucleus treated with nocodazole and aphidicolin was considered to be GI, since DNA synthesis in the treated embryos was rarely observed. In a preliminary study, the treatment of two-cell embryos with $3 \mu \mathrm{g}$ aphidicolin $\mathrm{ml}^{-1}$ for $3 \mathrm{~h}$ did not significantly inhibit the development to blastocysts. The recipient oocytes were considered to be at the $\mathrm{M}$ stage, since all (30/30) nuclei of male fetal germ cells at the GI stage showed premature chromosome condensation within $\mathrm{Ih}$ after fusion with enucleated oocytes, which was performed in a separate experiment (Y. Tsunoda and Y. Kato, unpublished).

The present study used serial nuclear transfer, which is not generally required in domestic animals, on the basis of the results of a previous study (Tsunoda and Kato, 1997). Enucleated oocytes receiving a nucleus from four-cell embryos did not develop after transfer to recipient females, but young were obtained after renuclear transfer to enucleated fertilized eggs. Although the exact reason why renuclear transfer is effective in mice is not clear, unknown factors that enhance the developmental ability of reconstituted eggs to term may be present in the cytoplasm of fertilized eggs (Tsunoda and Shioda, 1988). A difference in the timing of embryonic genome activation, at the two-cell stage in the mouse (Bolton et al., 1984) and at the 8-16-cell stage in domestic animals (Camous et al., 1986), may be a factor. However, Cheong et al.(1993) obtained live mice after transfer of nuclei from four-cell embryos to enucleated oocytes without the second transfer to enucleated embryos. The most likely explanation for this discrepancy is the difference in the method used to fuse the donor blastomere with cytoplasm of recipient oocytes, HVJ in our previous report (Tsunoda and Kato, 1997) and electrical stimulation in the report of Cheong et al.(1993). The findings of Cheong et al. (1993) suggest that serial nuclear transfer is not necessary, at least with certain nuclei.

In the present study, single nuclear transfer of ICM and trophectoderm nuclei was not attempted. Of the 101 oocytes that formed a pronucleus after receiving a trophectoderm nucleus, 27 had a polar body. The ability of embryos reconstituted from oocytes with a polar body to develop into blastocysts was low compared with those reconstituted from oocytes without a polar body, and none developed to live mice after embryo transfer. Although the reason for this low developmental ability was not clear, it may have been due to chromosomal abnormality of oocytes since four of eight oocytes with a polar body were haploid, while 12 of 15 oocytes without a polar body had the diploid chromosome constitution in a separate experiment (unpublished). Cheong et al. (1993) also reported that an extrusion of a polar body is related to subsequent developmental potential. Kono et al. (1992) found that most nuclear transferred oocytes excluded a polar body and reconstituted oocytes developed to young, but the cell cycle of their nuclei was at the G2 stage.

The fate of the trophectoderm is considered to be to form the placenta and the fetal membranes and not to participate in the formation of the fetus proper. However, the present study indicated that the nucleus of trophectoderm cells of the blastocyst presumed to be at the G1 stage of the cell cycle could be reprogrammed in a serial nuclear transfer to the cytoplasm of unfertilized oocytes activated by electrostimulation and then to enucleated fertilized embryos. Wilmut et al. (1997) reported that nuclei at the Go phase of the cell cycle from cell lines that were established from sheep embryo, fetal fibroblast and mammary gland could be reprogrammed in a single nuclear transfer to enucleated oocytes. The nature of the reprogramming factor(s) possibly present in the cytoplasm of unfertilized oocytes remains to be clarified. 
The authors thank Y. Kaneda, Institute for Molecular and Cellular Biology, Osaka University, for providing HVJ. The present study was supporłed by a grant from the Japanese Ministry of Agriculture, Forestry and Fisheries (Biotecnology), Special Coordination Funds for Promoting Science and Technology from the Science and Technology Agency, a Grant in Aid for Scientific Research Number 08556046 and the Human Science Foundation.

\section{References}

Bolton VN, Oades PJ and Johnson VN (1984) The relationship between cleavage, DNA replication and gene expression Journal of Embryology and Experimental Morphology 79 139-163

Camous S, Kopechy V and Flechon JE (1986) Autoradiographic detection of the earliest stage of [3H]uridine incorporation into the cow embryo Biology of the Cell 58 195-200

Campbell KHS, McWhir J, Ritchie WA and Wilmut I (1996) Sheep cloned by nuclear transfer from a cultured cell line Nature 380 64-66

Cheong HT, Takahashi $\mathrm{Y}$ and Kanagawa $\mathrm{H}$ (1993) Birth of mice after transplantation of early cell-cycle-stage embryonic nuclei into enucleated oocytes Biology of Reproduction $48958-963$

Collas P and Robl JM (1991) Relationship between nuclear remodelling and development in nuclear transplant rabbit embryo Biology of Reproduction 45 455-465

Collas P and Barnes FL (1994) Nuclear transplantation by microinjection of inner cell mass and granulosa cell nuclei Molecular Reproduction and Development 38 264-267

Fulton BP and Whittingham DG (1978) Activation of mammalian oocytes by intracellular injection of calcium Nature 273 149-151

Handyside AH and Johnson MH (1978) Temporal and spatial pattern of the synthesis of tissue-specific polypeptides in the preimplantation mouse embryo Journal of Embryology and Experimental Morphology 87 27-45

Hogan B, Beddington R, Costantini F and Lacy E (1994) Manipulating the Mouse Embryo pp 20-I13 Cold Spring Harbor Laboratory, New York

Illmensee K and Hoppe PC (198I) Nuclear transplantation in Mus musculus; developmental potential of nuclei from preimplantation embryos Cell $\mathbf{2 3}$ 9-18
Kato $Y$ and Tsunoda $Y$ (1995) Nuclear transfer of inner cell mass cells and fetal germ cells at different cell cycles into enucleated zygotes at the $M$ phase in the mouse Journal of Reproduction and Development 41 345-351

Keefer CL, Stice SL and Matthews DL (1994) Bovine inner cell mass cells as donor nuclei in the production of nuclear transfer embryos and calves Biology of Reproduction 50 935-939

Kono T, Kwon OY, Watanabe T and Nakahara T (1992) Development of mouse enucleated oocytes receiving a nucleus from different stages of the second cell cycle Journal of Reproduction and Development 39 301-307

McGrath J and Solter D (1984) Inability of mouse blastomere nuclei transferred to enucleated zygotes to support development in vitro. Science 226 13171319

Modlinski JA (1981) The fate of inner cell mass and trophectoderm nuclei transplanted to fertilized mouse eggs Nature $292 \quad 342-343$

Smith LC and Wilmut I (1989) Influence of nuclear and cytoplasmic activity on the development in vivo of sheep embryos after nuclear transplantation Biology of Reproduction 40 1027-1035

Solter D and Knowles BB (1975) Immunosurgery of mouse blastocysts Proceedings of National Academy of Sciences USA 72 5099-5102

Tsunoda Y and Shioda Y (1988) Development of enucleated parthenogenones that received pronuclei or nuclei from fertilized mouse eggs Gamete Research 21 I5I-155

Tsunoda $Y$ and Kato $Y$ (1995) Development of enucleated mouse oocytes receiving PDGF and FGF treated male germ cells after activation with electrical stimulation Journal of Reproduction and Development 41 71-75

Tsunoda Y and Kato Y (1997) Full term development after transfer of nuclei from 4-cell and compacted morula stage embryos to enucleated oocytes in the mouse Journal of Experimental Zoology 278 250-254

Tsunoda Y, Tokunaga T, Sugie T and Katsumata M (1985) Production of monozygotic twins following the transfer of bisected embryos in the goats Theriogenology 24 337-342

Tsunoda Y, Yasui T, Nakamura K, Uchida T and Sugie T (1986) Effect of cutting the zona pellucida on the pronuclear transplantation in the mouse Journal of Experimental Zoology 240 119-125

Whittingham DG (1971) Culture of mouse ova Journal of Reproduction and Fertility Supplement 14 7-14

Wilmut I, Schnieke AE, McWhir J, Kind AJ and Campbell KHS (1997) Viable offspring derived from fetal and adult mammalian cells Nature $\mathbf{3 8 5}$ 810-813 